
Agama," Afkār Vol. 20 Issue 1 (2018): 143-178

\title{
ANALISIS TEORI PARADIGMA (PARADIGM THEORY) HANS KÜNG DALAM KAJIAN AGAMA
}

\author{
AN ANALYSIS OF HANS KÜNG'S PARADIGM THEORY \\ IN RELIGIOUS STUDY
}

\section{Mohd Khairul Naim Che Nordin}

Department of `Aqidah \& Islamic Thought. Academy of Islamic Studies. University of Malaya. 50603. Kuala Lumpur. Malaysia.

\section{Email: khairulnaim@um.edu.my}

\begin{abstract}
Khulasah
Kemajuan sains memperlihatkan kelahiran teori saintifik yang dimodifikasi untuk berfungsi memberi penjelasan terhadap fenomena agama dan sosial penganutnya. Antara contoh tersebut ialah berkembangnya teori paradigma yang pada awalnya diperkenalkan oleh Thomas Kuhn untuk bidang sains tabii namun kemudian diduplikasi dengan beberapa perubahan oleh Hans Küng untuk kajian agama. Makalah ini bertujuan menjelaskan teori paradigma agama menurut Küng khusus pada aspek metodologi, kerangka serta ciri-cirinya yang cuba dibezakan dengan apa yang diperkenalkan oleh Kuhn. Melalui metode kualitatif deskriptif melibatkan pendekatan induktif, makalah mendapati teori yang cuba diketengahkan oleh Küng ini memperlihatkan pentafsiran agama pada aspek pensejarahan (historiografi) dan produk budaya seterusnya mengesampingkan aspek kajian yang lebih komprehensif dan konstruktif iaitu kombinasi aspek tekstual, kontekstual dan dogmatik atau kepercayaan sesuatu agama dan pengamalan ajaran penganutnya.
\end{abstract}

Kata kunci: teori paradigma; Thomas Kuhn; Hans Küng; sains; agama.

\footnotetext{
Abstract

Scientific advancement shows the emergence of a modified scientific theory to function in explaining the
} 
religious and social phenomena of its adherents. Among these examples is the development of a paradigm theory that was originally introduced by Thomas Kuhn for the field of natural science but later duplicated with some changes by Hans Küng for religious studies. This paper aims to explain the theory of religious paradigm according to Küng in particular on the methodological aspects, the framework and its features. Through descriptive qualitative methods involving inductive approach, the paper finds that this theory highlights the interpretation of religion in the aspect of historiography and cultural values and norms in turn overruns the more comprehensive and constructive aspects of the combination study of textual, contextual and dogmatic or religious beliefs and the practice of its adherents.

Keywords: paradigm theory; Thomas Kuhn; Hans Küng; science; religion.

\section{Pendahuluan}

Teori paradigma ialah sebuah teori anjakan yang diperkenalkan oleh Thomas S. Kuhn ${ }^{1}$ dikhususkan untuk

${ }^{1}$ Thomas S. Kuhn merupakan graduan fizik dari Universiti Harvard dan pernah bekerja di Harvard Radio Research Laboratory dengan melakukan kajian berkenaan radar kapal terbang perang. Selepas melanjutkan pengajian di peringkat Phd, beliau mula didedahkan dengan pandangan-pandangan Karl Popper khususnya berkenaan 'critical rationalism' dan dilantik sebagai editor bagi International Encyclopedia of Unified Science. Beliau seterusnya menerbitkan buku 'The Copernican Revolution' pada tahun 1957 dan kemudiannya dilantik untuk mengajar di Jabatan Falsafah dan Jabatan Sejarah Sains, Universiti California. Beliau menerbitkan bukunya, The Structure of Scientific Revolutions pada tahun 1962 dengan mengemukakan teori perubahan paradigma yang menarik perhatian ramai pihak. Ia diperakui sebagai buku akademik dalam bidang sains dan falsafah yang terbaik untuk separuh kedua abad ke-20 dengan jualan berjutajuta naskhah dan diterjemahkan ke 20 bahasa. Untuk huraian lanjut lihat Stefano Gattei, Thomas Kuhn's "Lingusitic Turn" and the Legacy of Logical Empiricism: Incommensurability, Rationality and the Search for Truth (Hampshire: Ashgate Publishing Limited, 2008), 
bidang sains tabii. Namun sebahagian sarjana antaranya Hans Küng berpandangan bahawa ia turut terpakai dalam bidang-bidang yang lain termasuklah dalam pengkajian agama dan kemasyarakatan. Dengan kata lain, teori yang diperkenalkan dalam bidang sains teraplikasi untuk digunakan dalam bidang agama dengan beberapa pindaan dan perubahan. Bagi pendokong teori paradigma agama ini, penggunaan teori ini dilihat membantu dalam mengkaji dan memahami 'perkembangan' agama secara lebih menyeluruh. Namun, sebelum dibahaskan teori paradigma agama secara lebih lanjut, adalah penting untuk dijelaskan terlebih dahulu konsep teori paradigma agama secara konseptual seperti yang dikemukakan oleh Kuhn.

Kuhn dalam bukunya The Structure of Scientific Revolutions menyatakan paradigma sebagai 'apa' yang dikongsi oleh ahli-ahli dalam komuniti saintis. ${ }^{2}$ Ia merupakan piawai atau 'standard' yang mengatur, menentu dan memastikan proses pemecahan masalah dalam ilmu pengetahuan. Ilmu pengetahuan yang lahir dari kerangka paradigma ini dinilai sebagai ilmu yang 'normal' dan ahliahli yang berpegang kepada paradigma yang sama turut mempunyai pandangan yang sama. Sesuatu itu menjadi normal selepas melalui fasa perkembangan yang panjang sehinggalah ia mencapai tahap matang sehingga diterima ramai orang. ${ }^{3}$

Perubahan paradigma berlaku apabila berlakunya perubahan andaian asas atau perubahan paradigma dalam teori sains sedia ada. Ia merupakan satu revolusi saintifik (dinamakan sebagai scientific revolution) yang berlaku apabila ahli komunitinya mula mempersoalkan 'kesempurnaan' paradigma tersebut. Apabila mereka

90-91 dan Thomas Nickles, Thomas Kuhn (Cambridge: Cambridge University Press, 2003), 1.

2 Thomas S. Kuhn, The Structure of Scientific Revolutions (Chicago: The University of Chicago Press, 1970), 43-50.

${ }^{3}$ Ibid. 
memilih kaedah, nilai dan sistem yang baru maka perubahan ke arah paradigma yang baru akan berlaku. Ia satu revolusi kerana keseluruhan paradigma akan berlaku perubahan. ${ }^{4}$

Krisis ini perlu berlaku bagi memastikan ilmu terus berkembang dan tidak kaku. Antara contoh paradigma yang telah melalui perubahan dan akhirnya tidak digunakan lagi adalah seperti paradigma Ptolemian yang berpaksikan bumi sebagai pusat alam, paradigma Copernican yang melihat matahari sebagai pusat alam dan paradigma Newtonian yang melihat alam berjalan di bawah pengaruh sistem dan hukum gerak Newton. ${ }^{5}$ Secara mudahnya perkembangan dan 'kematian' paradigma boleh difahami seperti berikut:

$$
\begin{gathered}
\text { pra-ilmu - ilmu normal - krisis - revolusi - ilmu normal } \\
\text { baru - krisis baru }
\end{gathered}
$$

\section{Teori Paradigma Agama menurut Hans Küng}

Hans Küng ${ }^{6}$ memperkenalkan konsep analisis paradigma (paradigm analysis) dalam pengkajian agama melalui dua buah bukunya Does God Exist?: The Problem of God in the Modern World (1978: 16 tahun selepas penerbitan buku Kuhn) dan Theology for the Third Millennium (1987). Ia dikembangkan lagi melalui buku beliau 'Global Responsibility' (1991) yang untuk pertama kalinya membawa tema 'etika global' sebagai antara konsep serta

\section{${ }^{4}$ Ibid.}

${ }^{5}$ Ibid., 23 dan 43-50.

${ }^{6}$ Prof. Hans Küng merupakan tokoh dialog antara agama dan Profesor Emeritus di University of Tübingen, Jerman. Beliau merupakan mantan Presiden Kehormat Yayasan Etika Global (Global Ethic Foundation) yang merupakan sebuah pertubuhan yang mengembangkan idea-idea beliau khususnya dalam persoalan etika sejagat sebagai asas keamanan global. Beliau juga telah menghasilkan lebih lima puluh buah buku dan ratusan artikel jurnal serta kertas kerja dalam bidang teologi, perbandingan agama, dialog antara-agama, politik, ekonomi dan lain-lain. F.L. Cross dan E.A. Livingtone, The Oxford Dictionary of the Christian Church (Oxford: Oxford University Press, 2005), 942-943. 
strategi keamanan antara-agama dengan pendekatan analisis paradigma. ${ }^{7}$ Bagi beliau, pencapaian keamanan antara-agama bergantung kepada pengetahuan menyeluruh seseorang terhadap agama di mana analisis paradigma adalah medium untuk memahami kepercayaan manusia. Menurut Küng: "Anyone who want to serve peace cannot avoid a paradigm analysis". ${ }^{8}$

Bagi beliau, salah satu sebab utama berlakunya pertentangan antara penganut agama yang berbeza, bahkan perselisihan sesama penganut dalam sesuatu agama itu sendiri dikatakan adalah kerana paradigma lama yang masih wujud di samping paradigma baru yang terbentuk hasil interaksi agama dengan perkembangan semasa. Perbezaan dalam menghadapi perubahan menimbulkan pertentangan. Oleh kerana itu analisis paradigma adalah penting supaya setiap penganut mengetahui aspek sepunya yang boleh mereka persetujui dan masalah yang boleh diselesaikan secara bersama. ${ }^{9}$ Namun bagaimanakah ia mampu diaplikasikan untuk mencapai matlamat yang dinyatakan di atas? Perbincangan seterusnya akan menghuraikan definisi dan metodologi paradigma agama, perbezaan paradigma dengan agama, ciri-cirinya dan pandangan berkenaan paradigma pascamoden sebagai paradigma setiap agama.

${ }^{7}$ Penggunaan pendekatan analisis ini juga boleh diteliti melalui tiga buah bukunya iaitu Judaism, Christianity dan Islam di mana beliau menghuraikan ketiga-tiga agama ini menggunakan pendekatan menganalisis 'paradigma-paradigma' agama dan perubahan yang berlaku dalam agama tersebut.

${ }^{8}$ Hans Küng, Global Responsibility: In Search of a New World Ethic terj. John Bowden (Oregon: Wipf and Stock, 1991), 126.

${ }^{9}$ Ibid. 


\section{Definisi dan Metodologi}

Menurut Küng, setiap agama mengalami anjakan paradigmanya yang tersendiri. Tiada agama yang terkecuali dari menerima perubahan anjakan ini. ${ }^{10}$ Menurutnya:

"For on the one hand there can be no religion without a paradigm". ${ }^{11}$

Selaras dengan itu, Küng mendefinisikan paradigma sebagaimana berikut:

"With paradigm we mean (following the definition taken over from Thomas S. Kuhn and constantly used in this book) of a total constellation: the conscious-unconscious 'total constellation of convictions, values, and patterns of behaviour' that obviously shape religion but not just religion." 12

Dalam konteks ini Küng menggunakan maksud yang diperkenalkan oleh Kuhn yang mendefinisikan paradigma sebagai sebuah set gugusan menyeluruh (total constellation) yang disedari atau tidak disedari (consciousunconscious) oleh penganut agama berkenaan kepercayaan, nilai dan corak perlakuan yang secara jelas membentuk sesebuah agama tetapi bukan hanya agama (iaitu dengan maksud ia melangkaui agama dan turut membabitkan aspek ekonomi, perundangan, politik, sains, kebudayaan dan lainlain sektor yang mempengaruhi masyarakat).

Justeru, paradigma yang dimaksudkan ini merujuk kepada paradigma berskala besar dan menyeluruh yang disebut sebagai paradigma makro (macroparadigms). Ia tidak menyentuh perubahan pandangan-pandangan yang kecil (paradigma mikro - micro atau mesoparadigms). ${ }^{13}$

\footnotetext{
${ }^{10}$ Hans Küng, Theology for the Third Millennium: An Ecumenical View (New York: Doubleday, 1988), 210.

11 Ibid., 223.

12 Ibid., 211

${ }^{13}$ Ibid.
} 
Selain itu, paradigma yang dimaksudkan ini juga bukan sekadar paradigma agama tetapi juga merupakan paradigma masyarakat kerana ia membabitkan masyarakat. Namun agama adalah faktor utama kepada tercetusnya sesuatu paradigma tersebut. ${ }^{14}$

Pada aspek metodologi, analisis paradigma bermaksud satu usaha menganalisa keseluruhan gugusan (constellations) dalam agama, bagaimana ia terbentuk, berkembang menjadi matang dan kemudiannya pupus, kaku atau 'menjadi fosil' (fossilized). ${ }^{15}$ Ia juga mencari penjelasan bagaimana paradigma 'yang telah menjadi fosil' tersebut terus kekal dalam sesuatu masa walaupun ia telah dianggap menjadi tradisi. Penggunaan perkataan fosil bagi paradigma lama kerana paradigma tersebut masih kekal dianuti sebahagian penganut namun tidak lagi berkembang. ${ }^{16}$

Di samping itu, menganalisa paradigma juga bermaksud mengkaji kebangkitan paradigma-paradigma baru serta melihat kemungkinan munculnya perspektif atau pandangan baru dalam sesuatu agama di masa depan. Berdasarkan huraian yang diberikan, Küng berpandangan bahawa teori ini menjadi bukti atau hujah bahawa setiap agama sentiasa dan berterusan mengalami perubahan. Ia dikatakan menyangkal 'gambaran' yang tersebar di kalangan para penganut agama selama ini yang melihat bahawa agama yang mereka anuti adalah kekal sama. ${ }^{17}$

Berikut merupakan contoh perubahan paradigma yang berlaku dalam ajaran Kristian. Ia bermula dari paradigma awal Kristian (early Christian apocalyptic paradigm) dengan kemunculan tokoh seperti Jesus, Paul dan penulisan Gospel di abad pertama kepada paradigma Helenistik

\footnotetext{
${ }^{14}$ Ibid.

15 Hans Küng, Islam: Past, Present and Future, (Oxford: Oneworld Publications 2007), xxvii.

${ }^{16}$ Ibid.

${ }^{17}$ Ibid.
} 
gereja (early Church Hellenistic paradigm) yang menyaksikan percampuran ajaran ini dengan budaya helenistik Rom di abad pertama sehingga abad ke 7 . Ia seterusnya berubah kepada paradigma mediaeval (mediaeval Roman Catholic paradigm) pada abad ke-11 dengan munculnya faham skolastik dan perpecahan gereja timur dan barat.

Ia seterusnya berubah kepada paradigma reformasi Protestan (reformation Protestant paradigm) pada abad ke16 dengan lahirnya gerakan reformasi Kristian oleh Luther dan Calvin. Seterusnya ia berubah kepada paradigma era pencerahan (enlightenment-modern paradigm) pada abad ke-17 dan 18 dengan lahirnya falsafah moden, perkembangan sains tabii dan teori bernegara yang mencetuskan Revolusi Perancis sehinggalah yang terkini bermula abad ke-20 iaitu paradigma kontemporari pascamoden (contemporary ecumenical paradigm (postmodern)). Enam perubahan yang berlaku ini memakan masa selama dua puluh kurun bermula kurun pertama sejak perutusan Jesus sehinggalah ke abad-20. ${ }^{18}$

Manakala perubahan paradigma dalam Islam pula ialah bermula dengan paradigma komuniti Islam asal (paradigm of the original Islamic community) (622-661M) yang merujuk kepada kelahiran komuniti dan ajaran Islam yang pertama oleh Nabi Muhammad. Ia kemudiannya berubah kepada paradigma empayar Arab (paradigm of the Arab empire) sewaktu kekhalifahan Umayyah (661-750M) yang melahirkan empayar oleh orang-orang Arab. Seterusnya ia berubah kepada paradigma klasik berkenaan Islam sebagai agama dunia (classical paradigm of Islam as a world religion) yang berlangsung sewaktu kekhalifahan Abbasiyyah sehingga kejatuhannya (750-1258M) di mana ia merujuk kepada kelahiran pelbagai empayar di Sepanyol,

${ }^{18}$ Hans Küng, Global Responsibility, 123 dan Hans Küng, Islam: Past, Present and Future, 582. 
Mesir dan India serta peluasan empayar Abbasiyyah dan kemunculan mazhab dalam bidang pemikiran dan fiqh.

Ia kemudiannya berubah kepada paradigma ulama dan sufi (paradigm of the Ulama and Sufis) dengan berkembangnya gerakan sufi di dunia Islam bermula abad ke-13. Dari paradigma ini ia berubah kepada paradigma modernisasi (modernization paradigm) di abad 17-20 dengan berlakunya kolonialisasi oleh kuasa Eropah ke dunia Islam sehingga kejatuhan empayar Uthmaniyyah. Paradigma terkini disebut berubah pula kepada paradigma kontemporari (pascamoden) (contemporary paradigm (postmodern)) selepas perang dunia kedua yang memperlihatkan kelahiran beberapa gerakan seperti nasionalisme Arab, Pan-Islamisme, Reformisme Islam, Tradisionalisme Islam dan lain-lain. ${ }^{19}$

Justeru, berbanding menekankan apa yang disebut sebagai persoalan 'teologi klasik' seperti hubungan Tuhan dengan manusia dalam mengkaji agama, beliau lebih memfokuskan kepada analisis masa dan peristiwa yang berlaku dalam setiap agama. ${ }^{20}$ Beliau mendakwa dengan metode yang digunakan ini maka agama akan dinilai secara keseluruhan dengan mengambil kira setiap perkembangan peristiwa dan masanya. Bahkan beliau mengatakan kaedah yang digunakan dalam kajian agama sebelum ini seperti analisis teks, pencarian arkeologi dan lain-lain adalah tidak mencukupi untuk memahami agama yang kompleks seperti Yahudi, Kristian dan Islam. Justeru, kajian yang beliau perkenalkan ini dikatakan mampu menilai agama secara keseluruhan bermula dari perkembangan dan kesan sejarah sesuatu ajaran sehinggalah kepada struktur, corak kepercayaan, pemikiran, perasaan dan perbuatan penganutpenganutnya. ${ }^{21}$

${ }^{19}$ Ibid., 584.

${ }^{20}$ Hans Küng, Global Responsibility, 110.

${ }^{21}$ Ini kerana bagi Küng, agama adalah sebuah sistem yang hidup dan digunakan untuk panduan kehidupan. Ia sentiasa berkembang dan 
Mohd Khairul Naim, "Analisis Teori Paradigma Hans Küng dalam Kajian Agama," Afkār Vol. 20 Issue 1 (2018): 143-178

semakin kompleks berdasarkan perkembangan masa dan suasana. Justeru, mengambil contoh tiga agama yang dikelompokkannya sebagai 'the three Abrahamic Religions' iaitu Yahudi, Kristian dan Islam, beliau melihat ketiga-tiga agama ini perlu difahami secara keseluruhan, berdasarkan paradigma berbeza tetapi melalui satu sejarah kebudayaan (one cultural history) yang sama. Lihat Ibid.,111 $\& 120$. 
Mohd Khairul Naim, "Analisis Teori Paradigma Hans Küng dalam Kajian Agama," Afkār Vol. 20 Issue 1 (2018): 143-178

\section{Rajah 1: Kronologi perubahan paradigma dalam ajaran Kristian $^{22}$}

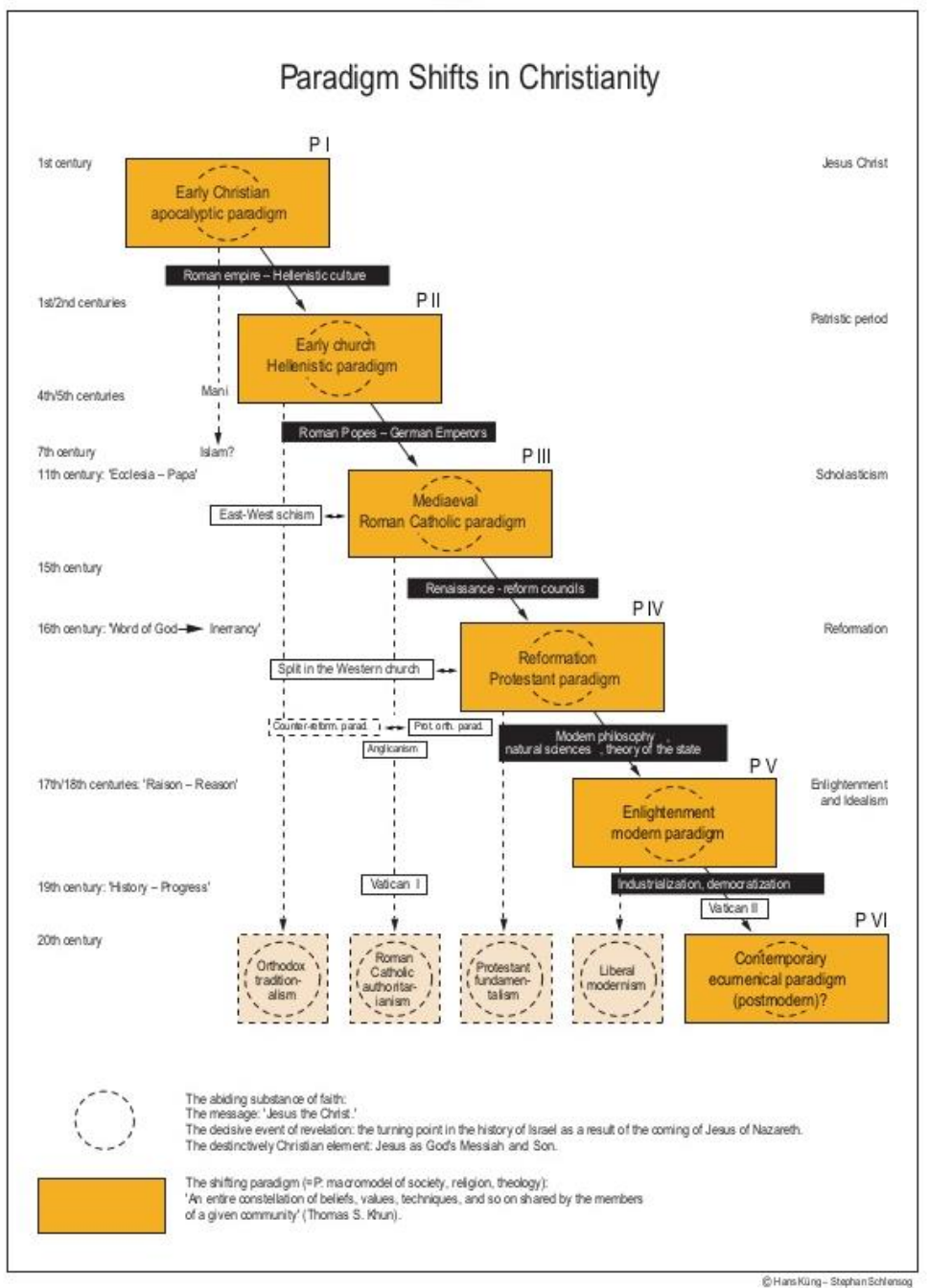

${ }^{22}$ Najiah Martiyam ed., Jalan Dialog Hans Kung dan Perspektif Muslim, terj. Mega Hidayati et.al (Yogyakarta: Program Studi Agama dan Lintas Budaya, t.t), 52. 
Mohd Khairul Naim, "Analisis Teori Paradigma Hans Küng dalam Kajian Agama," Afkār Vol. 20 Issue 1 (2018): 143-178

\section{Rajah 2: Kronologi perubahan paradigma dalam ajaran Islam $^{23}$}

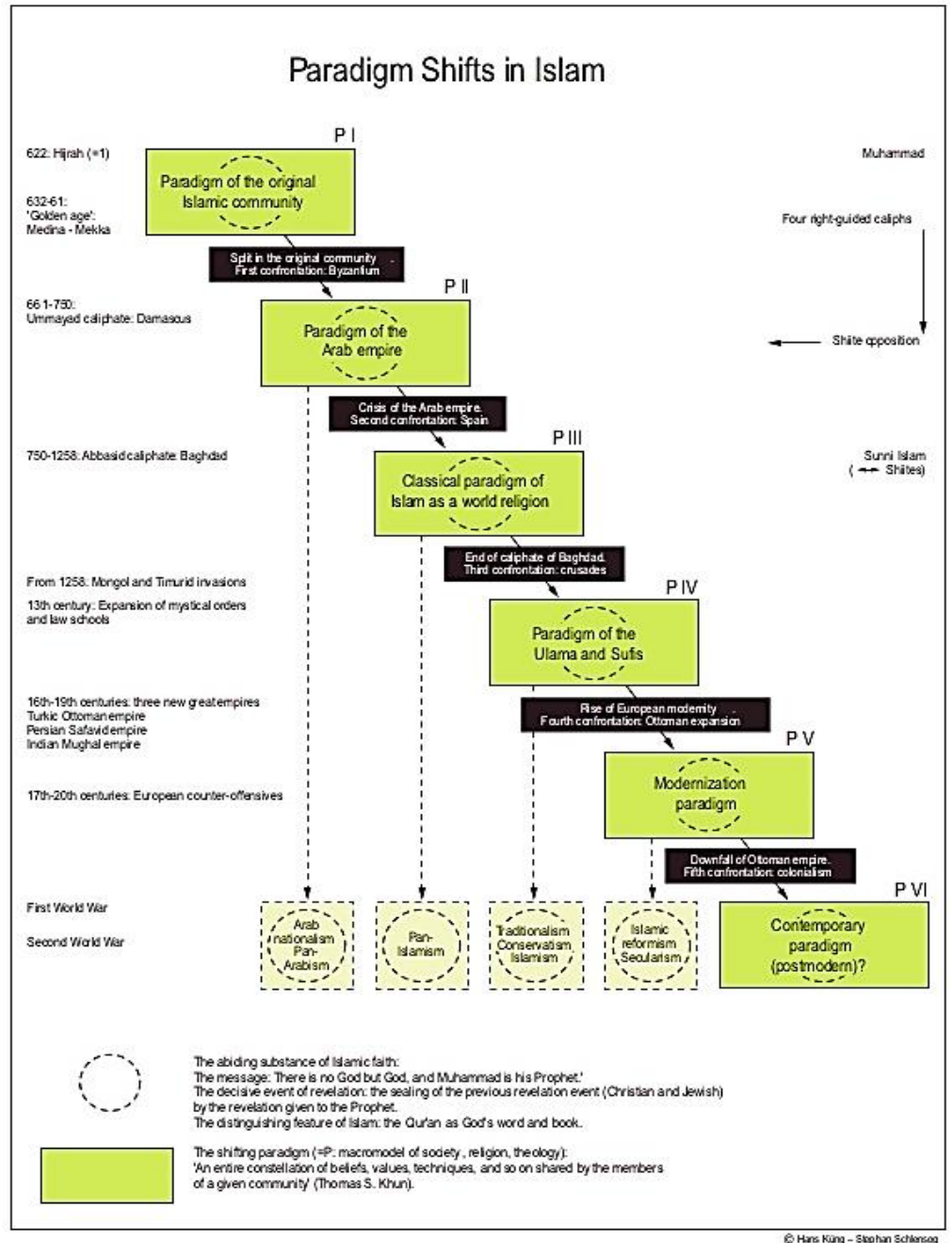

${ }^{23}$ Ibid., 53. 


\section{Perbezaan Paradigma dengan Agama}

Menurut Küng, terdapat perbezaan yang ketara antara paradigma dengan agama. Agama adalah seumpama sebuah model. Ia membentuk keyakinan berasaskan kesedaran seseorang berkenaan pandangan hidup mereka. Ia juga merupakan sebuah cara hidup berasaskan ajaran yang bersifat mutlak dan bersumberkan 'kebenaran yang tertinggi' ${ }^{24}$

Dari penjelasan ini, agama bukannya paradigma tetapi ia hidup dan berkembang melalui paradigma yang berlangsung melalui tahap-tahap tertentu dalam sejarah. Agama itu hidup dan berkembang pada setiap zaman dengan paradigma-paradigma yang berbeza. ${ }^{25}$ Agama merupakan sebuah keyakinan yang dianuti secara sedar manakala paradigma teraplikasi dalam setiap zaman dalam keadaan seseorang itu menyedari ataupun tidak menyedari ia berpegang kepada sesebuah paradigma tersebut.

Küng memberikan beberapa anologi untuk memudahkan kefahaman berkenaan perbezaan antara kedua-duanya. Agama boleh diumpamakan sebagai kandungan dan paradigma adalah bentuknya, agama juga seumpama gambar manakala paradigma adalah bingkainya dan agama juga boleh diumpamakan ibarat teks dan paradigma adalah konteksnya. ${ }^{26}$

Contoh perbezaan antara agama dan paradigma boleh diteliti melalui konsep pertukaran anutan (conversion). Menurut Küng, sekiranya seorang penganut Kristian bermazhab Katolik berasa kurang senang dengan pegangannya lalu bertukar menganut Protestan, atau seorang Protestan melihat kelebihan ajaran Katolik yang lebih bersifat 'sejagat' lalu menukar anutannya kepada Katolik, maka ini dinamakan sebagai perubahan

\footnotetext{
${ }^{24}$ Hans Küng, Theology for the Third Millennium, 212.

${ }^{25}$ Ibid.

${ }^{26}$ Ibid., 210-211.
} 
paradigma. Agamanya tetap kekal dengan Kristian namun paradigmanya berubah.

Namun, sekiranya seorang penganut Kristian berubah pegangannya kepada ajaran Buddha maka perubahan ini bukannya perubahan paradigma tetapi perubahan agama. Justeru, menganut ajaran Kristian difahami sebagai mengikuti ajaran Christ dan menjadi penganut Buddha bermakna menuruti jejak langkah Buddha. ${ }^{27}$

Berdasarkan huraian di atas, paradigma dan agama itu berbeza tetapi saling memerlukan. Seseorang mungkin menganuti agama yang sama namun paradigmanya berbeza. Doktrinnya tetap kekal, cuma yang mungkin terjadi adalah berubahnya paradigma dalam menanggapi perubahan-perubahan yang berlaku dalam anutannya sahaja.

\section{Ciri-Ciri Paradigma Agama}

Terdapat beberapa ciri paradigma agama yang boleh digariskan berdasarkan huraian Küng iaitu:

a. Proses perkembangan paradigma tidak boleh disatukan untuk semua sektor dan disiplin. Sebagai contoh penggunaan istilah 'moden' untuk seni (art), 'moden' untuk sains dan 'moden' untuk agama adalah berbeza dari sudut subjek dan tahapan sejarahnya. Perubahan paradigma dalam bidang kesenian berbeza bentuknya dengan perubahan paradigma dalam agama. ${ }^{28}$ Sebagai contoh, berubahnya paradigma Hellenistik gereja di kurun pertama dan kedua tidak mengubah dan memberi kesan kepada perubahan paradigma seni di kurun yang sama. Ini kerana subjeknya saling berbeza. Untuk itu, Küng berpandangan sekiranya pengkaji ingin meneliti

27 Ibid.

${ }^{28}$ Ibid., 214. 
paradigma agama maka yang perlu ditelitinya ialah latar belakang sejarah agama. ${ }^{29}$

b. Perubahan paradigma berlaku berasaskan tahap-tahap yang berlaku dalam sejarah dan penafsiran terhadapnya adalah relatif. Dengan kata lain, proses pembahagian perubahan paradigma dan subjeknya adalah di bawah pengetahuan dan tafsiran penyelidik. Justeru, pembahagiannya mungkin sahaja berbeza antara penyelidik dengan penyelidik yang lain. Seperti yang dimaklumi, paradigma berkait dengan masa dan ia tidak boleh dihuraikan tanpa aspek masa dan penilaian sejarah. Oleh itu, menurut Küng penilaian seseorang terhadap paradigma dan perubahannya adalah relatif kerana pentafsiran seseorang terhadap sejarah juga berasaskan pengetahuannya yang relatif. ${ }^{30}$ Walaupun fakta dan peristiwa sejarah kekal tidak berulang, namun sejarah sentiasa terbuka kepada pentafsiran. Dalam hal ini, pengkaji perlu melihat segala fakta secara adil dan dalam masa yang sama tidak menutup atau menafikan pandangannya sendiri. Di samping itu, pengkaji perlu mengambil dan memilih fakta dan peristiwa sejarah yang paling

29 Ibid., 215. Untuk maklumat lanjut berkenaan perbincangan sarjana Barat mengenai sejarah dan pensejarahan sila lihat Allan Megill, Historical Knowledge, Historical Error: A Contemporary Guide to Practice (London: The University of Chicago Press, 2007). Untuk maklumat lanjut berkenaan modeniti dan perkembangannya sila lihat Bill Brugger dan Kate Hannan, Modernisation and Revolution (Kent: Croom Helm Ltd, 1983).

${ }^{30}$ Bagi Küng, sejarah ditentukan berdasarkan kepentingan sejarawan dan sudut pandang serta perspektifnya yang tertentu. Oleh itu ia tidak bebas nilai. Ia sama seperti situasi ahli fizik yang merungkai permasalahan kajiannya. Ia tidak objektif serta berdiri bebas dari penyelidik kerana hasil kajiannya tertakluk kepada paradigma tertentu termasuklah hanya bergantung ke atas pengetahuan penyelidik itu sahaja. Hans Küng, Theology for the Third Millennium, 213. 
dipersetujui oleh para sejarawan bagi memastikan ianya tepat dan sah. ${ }^{31}$

c. Sejajar dengan pandangan Kuhn tentang paradigma sains, perubahan paradigma agama juga hanya akan berlaku apabila sesuatu idea atau gerakan itu matang, dengan maksud telah dipersembahkan ke khalayak umum, diterima masyarakat dan membentuk pandangan yang normatif. Ini bermakna sesuatu pandangan yang bertentangan dengan paradigma di suatu zaman tidak akan mampu diubah menjadi sebuah paradigma yang baru sekiranya ia masih di tahap idea. $^{32}$

31 Sebagai contoh, menurut Küng, sesiapa sahaja boleh menentukan di manakah tahap-tahap kemunduran dan kebangkitan Eropah namun yang penting ia harus berdasarkan fakta yang tepat. Baginya sesiapa juga boleh meletakkan permulaan paradigma zaman moden dengan bermulanya 'renaissance' (walaupun gerakan pencerahan itu pada mulanya berorientasikan perkembangan di zaman gelap) atau menetapkannya kepada gerakan 'reformation' di abad ke-16. Pengkaji juga boleh menggariskan mulanya zaman moden di abad-17 dan 18 dengan munculnya aliran falsafah dan disiplin sains yang baru serentak dengan berkembangnya sekularisasi. Namun bagi Küng, zaman moden mula muncul bermula di abad ke-17 dan 18 berurutan dari perubahan paradigma reformation-Protestant di abad ke-16 yang sebelum itu terhasil dari paradigma sebelumnya iaitu paradigma Roman Katolik zaman pertengahan di abad ke-11. Bagi beliau tokohtokoh penting zaman moden ialah Descartes, Galileo, Newton, Hume dan Kant dan bukannya tokoh seperti Luther yang bersikap anti demokratik dan masih berpegang kepada pandangan zaman pertengahan. Justeru, Martin Luther dikelompokkan di era reformation abad ke-16. Justeru di sini Küng memberi justifikasi pentingnya sejarah yang tidak hanya dilihat berasaskan fakta tetapi memerlukan pentafsiran, pandangan, kriteria dan kepentingan tertentu yang datang dari pengkaji itu sendiri. Antara contoh penafsiran sejarah dan bagaimana teori paradigma memainkan peranannya boleh diteliti kepada huraian Küng tentang ajaran Kristian, doktrin dan sejarah perkembangan Eropah. Lihat Ibid., 213-214.

32 Sebagai contoh, idea-idea berkenaan eksistensialisme telah dipelopori oleh Kierkegaard dan Dostoyevsky di abad ke-19. Namun falsafah dan teologi eksistensial ini hanya berkembang sejak krisis Perang Dunia Pertama iaitu di permulaan abad ke-20. Justeru, di era Kierkegaard 


\section{d. Perubahan sesebuah paradigma agama kepada} paradigma yang lain tidak melenyapkan paradigma yang terdahulu. Ia tidak terjadi dalam bidang sains tabii kerana paradigma yang terkini dalam disiplin sains bersifat membatalkan paradigma sebelumnya. Apabila paradigma lama digantikan dengan yang baru, paradigma lama itu tidak lagi diperakui kesahannya. ${ }^{33}$ Dalam kajian sains, hipotesis yang dijalankan berdasarkan bukti-bukti empirikal. Kajian berbentuk empirikal ini akan menentukan secara jelas dan muktamad sama ada sesuatu teori itu benar dan sah atau sebaliknya. Dengan asas ini paradigma baru mampu (dan dipaksa) bertahan lama berpandukan bukti-bukti yang membenarkan paradigma tersebut. Situasi ini berbeza dengan bidang agama ${ }^{34}$ di mana paradigma lama bukan sahaja tidak lenyap dengan munculnya paradigma baru, bahkan paradigma itu kekal bertahan bersama-sama berkembangnya paradigma baru..$^{35}$ Sebagai contoh, pandangan

ideanya hanyalah idea sehinggalah ia diterima umum dan diiktiraf hingga terbentuknya sebuah paradigma baru di abad ke-20 menggantikan paradigma abad ke-19. Ibid., 214. Untuk melihat perkembangan eksistensialisme dan ideanya lihat Frederick Copleston, A History of Philosophy: Logical Positivism and Existentialism (New York: Continuum, 2003).

33 Sebagai contoh apabila paradigma 'Ptolemaic' digantikan dengan paradigma 'Copernican', pandangan-pandangan Ptolemy dan disiplin lapangan yang berkembang dan berkaitan dengannya adalah tertolak. Lihat Hans Küng, Theology for the Third Millennium, 215. Semangat romantisme tidak wujud dalam astronomi, fizik, kimia, biologi dan disiplin-disiplin sains lain kerana kajiannya yang bersifat empirikal.

34 Dalam perbincangan ini Küng merujuk kepada agama-agama utama (high religions) yang mempunyai doktrin dan ajaran yang kompleks sekaligus mampu bertahan lama dalam sejarah.

35 Ibid., 217. Bagi Küng hal ini berlaku kerana proses penginstitusian agama menjadi benteng bertahannya sesebuah paradigma. Ajaran yang diinstitusikan ini membentuk hukum, peraturan moral dan kuasa autoriti yang diperakui sebagai manifestasi wahyu atau arahan Tuhan. Institusi ini dikatakan sering disalah-guna dan dieksploitasi oleh pihak 
ortodoks tradisionalisme yang berkembang dalam ajaran Kristian pada abad pertama masih wujud dan kekal dianuti sebahagian penganut hingga kini. ${ }^{36}$

e. Perubahan paradigma dalam sesebuah agama tidak semestinya mencerminkan kemajuan untuk agama tersebut bahkan kadang-kala boleh membawa kemunduran. Sekali lagi ia dikatakan berbeza dengan sains kerana perubahan paradigma dalam ilmu sains tabii menandakan perkembangan yang progresif. Menurut Küng: ${ }^{37}$

"In religion, too, a paradigm change does not simply mean progress and only progress. In religion, too, much is gained in the paradigm change, but much that was true and good in the

agamawan dengan tujuan mempertahankan kuasa mereka sendiri, menutup penyelewengan yang dilakukan mereka atau mengaburi doktrin-doktrin yang bersalahan dengan ajaran asal. Dengan kuasa dan perintah wahyu serta atas nama agama dan Tuhan, golongan agamawan dan institusi yang mereka bentuk ini dianggap kudus, tidak boleh disentuh dan kebal dari sebarang kritikan dan pembaharuan. Justeru, dengan wujudnya apa yang disebut sebagai institusi-institusi dalam agama, paradigma lama dapat kekal bertahan walaupun paradigma baru telah muncul dan menyanggah sebarang idea dan pandangan paradigma lama. Di samping itu, faktor kedua bertahannya paradigma lama ialah kerana agama sebagai ajaran yang berkaitan dengan keabadian dan persoalan-persoalan ketuhanan telah menarik ramai manusia untuk menganutinya. Selagi adanya ajaran dan doktrin yang dibawa oleh agama maka selagi itu akan ada penganutnya. Dengan adanya penganut, agama dapat terus wujud dan relevan walau bagaimanapun bentuk-bentuk paradigmanya. Ibid., 218-219.

${ }^{36}$ Ibid., 123. Untuk rujukan berkenaan doktrin ortodoks Kristian dan perkembangannya kini, lihat Victor Roudometof et. al., Eastern Orthodoxy in A Global Age: Tradition Faces the Twenty-First Century (California: AltaMira Press, 2005) dan Trine Stauning Willert dan Lina Molokotos-Liederman (Innovation in the Orthodox Christian Tradition?: The Question of Change in Greek Orthodox Thought and Practice (Surrey: Ashgate Publishing Limited, 2012),

${ }^{37}$ Hans Küng, Theology for the Third Millennium, 220. 
earlier paradigm is lost, forgotten, or repressed."

f. Paradigma baru dalam sesebuah agama akhirnya boleh dilupakan atau diabaikan selepas beberapa lama akibat penafsiran-penafsiran yang berbeza. Justeru, dari kenyataan ini asas-asas dalam paradigma yang mulamula muncul boleh sedikit demi sedikit berubah hingga ketara berbeza dengan pandangan asalnya dan tidak menggambarkan lagi paradigma tersebut. Di samping sesebuah paradigma itu boleh memundurkan agama dan menjadikannya langsung berubah dari ajaran asal, paradigma juga boleh berubah ke arah bersifat autoritarian, berpegang dengan pegangan yang sempit, dan menindas. ${ }^{38}$ Sebagai contoh seperti yang boleh dilihat dalam perkembangan agama Kristian yang dikatakan berkembang dari hanya merupakan ajaran berkenaan dogma dan moral kepada paradigma mediaeval yang mula bertindak menghukum, menekan dan menindas para penganutnya. ${ }^{39}$ Perubahan paradigma seperti ini disebut mampu memberi kesan buruk kepada agama dan masyarakat. Oleh itu, bukan semua perubahan paradigma yang berlaku harus dipuji dan diraikan. ${ }^{40}$

${ }^{38}$ Berdasarkan keterangan yang diberikan, Küng menujukannya kepada beberapa gereja yang menolak sains dan teknologi serta sistem demokrasi. Menurut beliau, hal yang sama turut dihadapi oleh Islam dan agama-agama yang lain. Ibid., 221.

39 Ibid., 218. Untuk maklumat lanjut berkenaan perkembangan agama Kristian di era pertengahan (mediaeval) lihat James A. Sheppard, Christendom at the Crossroads: The Mediaeval Era (Kentucky: Westminster John Knox Press, 2005), Jennifer Kolpacoff Deane, $A$ History of Medieval Heresy and Inquisition (Plymouth: Rowman \& Littlefield Publishers 2011) dan Paola Tartakoff, Between Christian and Jew: Conversion and Inquisition in the Crown of Aragon, 12501391 (Pensylvania: University of Pensylvania Press, 2012)

${ }^{40}$ Hans Küng, Theology for the Third Millennium, 221. 
Justeru dari huraian di atas terdapat perbezaan antara paradigma sains seperti yang diperkenalkan oleh Thomas

Kuhn dengan paradigma agama menurut Küng iaitu:

Jadual 1: Perbezaan paradigma sains dengan agama ${ }^{41}$

\begin{tabular}{|l|l|}
\hline \multicolumn{1}{|c|}{ Paradigma sains } & \multicolumn{1}{|c|}{ Paradigma agama } \\
\hline $\begin{array}{l}\text { Paradigma baru melenyapkan } \\
\text { dan menyahkan paradigma } \\
\text { lama. }\end{array}$ & $\begin{array}{l}\text { Paradigma baru tidak melenyapkan } \\
\text { paradigma lama bahkan ia kekal } \\
\text { bersama-sama berkembangnya } \\
\text { paradigma yang baru. }\end{array}$ \\
\hline $\begin{array}{l}\text { Perubahan paradigma } \\
\text { menjamin kemajuan dan } \\
\text { perkembangan sains. }\end{array}$ & $\begin{array}{l}\text { Perubahan paradigma tidak } \\
\text { menjamin 'kemajuan' agama } \\
\text { bahkan ada kalanya ia } \\
\text { memundurkan perkembangan }\end{array}$ \\
$\begin{array}{l}\text { Sesebuah paradigma mampu } \\
\text { kekal bertahan lama melalui } \\
\text { kajian-kajian empirikal yang } \\
\text { menghasilkan bukti-bukti. Ia } \\
\text { seterusnya menjustifikasikan } \\
\text { keperluan paradigma itu untuk } \\
\text { kekal relevan. }\end{array}$ & $\begin{array}{l}\text { Sesebuah paradigma mampu kekal } \\
\text { bertahan dengan wujudnya institusi- } \\
\text { instusi dalam sesebuah agama. Ia } \\
\text { menjadi benteng mempertahankan } \\
\text { sesebuah paradigma dari terus }\end{array}$ \\
\hline $\begin{array}{l}\text { Sesebuah paradigma tidak } \\
\text { akan dilupuskan selagi mana } \\
\text { tiada bukti yang menyanggah } \\
\text { pandangan itu. }\end{array}$ & $\begin{array}{l}\text { Sesebuah paradigma boleh } \\
\text { diabaikan selepas beberapa masa } \\
\text { apabila munculnya penafsiran- } \\
\text { penafsiran baru. }\end{array}$ \\
\hline
\end{tabular}

\section{Paradigma Kontemporari (Pascamoden) sebagai Paradigma setiap Agama}

Dalam perbincangan sebelum ini dikatakan bahawa setiap agama mempunyai paradigma yang berbeza. Namun, berdasarkan keperluan semasa, Küng berpandangan bahawa setiap agama akan dan perlu mempunyai paradigma yang sama untuk masa kini dan akan datang. Ia dinamakan sebagai paradigma pascamoden.

Bagi Küng, istilah pascamoden muncul dalam bentuk yang kabur dan tidak mampu difahami dengan jelas. Ia

${ }^{41}$ Hans Küng, Theology for the Third Millennium, 211-221. 
bukan sekadar sebuah definisi untuk menggambarkan peralihan kepada era dunia yang baru tetapi juga sebuah konsep, slogan dan ekspresi kekecewaan masyarakat terhadap dunia moden. Kerana kekaburan itu maka pascamoden perlu didefinisikan dengan jelas dengan melihat struktur masalah yang membawa kepada perubahan ini serta perbezaannya dengan zaman moden. Atas asas tersebut beliau membentuk kerangka tersendiri dalam mendefinisikan paradigma pascamoden serta perbezaannya dengan paradigma moden. Perbezaan dimensi moden dan pascamoden ini boleh diteliti seperti berikut:

Jadual 2: Perbezaan paradigma moden dengan pascamoden $^{42}$

\begin{tabular}{|c|c|}
\hline Paradigma Moden & Paradigma Pascamoden \\
\hline $\begin{array}{l}\text { Paradigma moden khususnya } \\
\text { di Barat dan membabitkan } \\
\text { agama Kristian, disebut } \\
\text { bermula pada abad ke-17 } \\
\text { hingga akhir abad ke-20. }\end{array}$ & $\begin{array}{l}\text { Perubahan kepada paradigma } \\
\text { pascamoden bermula pada tahun } \\
\text { 1970-an dan 1980-an. Namun bibit- } \\
\text { bibit perubahan ini dikatakan telah } \\
\text { bermula seawal 1918 selepas } \\
\text { berakhirnya perang dunia pertama. }\end{array}$ \\
\hline $\begin{array}{l}\text { Dominasi kuasa Eropah } \\
\text { melahirkan Eurocentrism. Era } \\
\text { moden juga menyaksikan } \\
\text { berkembangnya fahaman fasis } \\
\text { serta pelbagai ideologi lain } \\
\text { yang dipasarkan ke serata } \\
\text { dunia. Dalam masa yang sama } \\
\text { berlakunya usaha imperialisasi } \\
\text { negara kuasa besar terhadap }\end{array}$ & $\begin{array}{l}\text { Dunia pascamoden menyaksikan } \\
\text { munculnya Polycentrism. Dalam } \\
\text { konteks geopolitik, kuasa dunia } \\
\text { tidak lagi dipegang oleh negara- } \\
\text { negara Eropah tetapi kini ditentukan } \\
\text { juga oleh negara di sebelah Timur } \\
\text { seperti China dan India. }\end{array}$ \\
\hline negara-negara yang lain. & $\begin{array}{l}\text { Dalam konteks ideologi, dunia } \\
\text { berubah kepada budaya pasca- }\end{array}$ \\
\hline $\begin{array}{lr}\text { Modeniti } & \text { menyaksikan } \\
\text { munculnya } & \text { kemuncak } \\
\text { kemajuan dalam sains dan } \\
\text { teknologi, pencapaian dalam }\end{array}$ & $\begin{array}{l}\text { ideologi iaitu budaya yang tidak } \\
\text { berdasarkan hanya satu ideologi } \\
\text { tetapi berorientasikan gagasan yang } \\
\text { plural dan dikongsi secara bersama. }\end{array}$ \\
\hline
\end{tabular}

${ }^{42}$ Hans Küng, Global Responsibility, 2-19. 


\begin{tabular}{|c|c|}
\hline $\begin{array}{l}\text { bidang pengindustrian serta } \\
\text { pelaksanaan demokrasi. } \\
\text { Namun dalam masa yang sama } \\
\text { pencapaian ini disalah-guna } \\
\text { oleh manusia untuk } \\
\text { kepentingan mereka. } \\
\text { Perkembangan industri juga } \\
\text { tidak disusuli dengan proses } \\
\text { pemeliharaan ekologi } \\
\text { manakala demokrasi pula tidak } \\
\text { digemblengkan bersama } \\
\text { dengan moraliti hingga } \\
\text { berlakunya pencabulan hak } \\
\text { manusia atas nama demokrasi. }\end{array}$ & $\begin{array}{l}\text { Dalam konteks agama, berlakunya } \\
\text { hubungan antara-agama yang secara } \\
\text { langsung membentuk komuniti } \\
\text { masyarakat yang membina } \\
\text { kerjasama dan perpaduan atas } \\
\text { persefahaman antara-agama. } \\
\text { (ecumenical world society) } \\
\text { Era pascamoden memperlihatkan } \\
\text { lahirnya pelbagai inovasi seperti } \\
\text { 'eco-technology' iaitu teknologi } \\
\text { pengurusan kitar semula yang } \\
\text { menghargai alam sekitar, 'energy- } \\
\text { saving technology iaitu teknologi } \\
\text { yang menggunakan sumber tenaga } \\
\text { bebas seperti kuasa solar, penciptaan } \\
\text { material yang mesra alam dan } \\
\text { penumpuan kajian serta } \\
\text { perkembangan teknologi untuk } \\
\text { kepentingan awam berbanding } \\
\text { untuk persenjataan sebelum ini. }\end{array}$ \\
\hline
\end{tabular}

Berdasarkan perbezaan dimensi moden dan pascamoden, maka Küng melihat wujudnya aspek-aspek positif yang lahir dari era pascamoden ini. Dengan kelebihan ini Küng membentuk ciri-ciri paradigma pascamoden yang boleh diteliti seperti berikut ${ }^{43}$ :

a. Perubahan kepada paradigma pascamoden tidak menghapuskan nilai yang terdapat di era moden tetapi mengubahnya kepada nilai yang lebih baik serta sesuai dengan perkembangan semasa. Perubahan nilai ini pula adalah di tahap asas (fundamental). Antara contoh perubahan tersebut ialah perubahan dari masyarakat yang tidak berpegang kepada etika (ethic-free society) kepada masyarakat yang bertanggungjawab dengan etika; perubahan dari teknologi yang bersifat

${ }^{43}$ Ibid., 20-23. 
menguasai manusia kepada teknologi yang memberi khidmat kemanusiaan kepada mereka; perubahan dari proses industrialisasi yang memusnahkan alam sekitar kepada industri yang memenuhi kepentingan dan keperluan sebenar manusia yang turut bergantung kepada pemeliharaan alam; dan perubahan dari bentuk demokrasi berasaskan perundangan semata kepada demokrasi yang 'hidup', di mana kebebasan dan keadilan dapat diselaraskan.

b. Perubahan-perubahan ini ditegaskan bukan untuk menghalang perkembangan sains, teknologi, industri dan demokrasi tetapi suatu perubahan sosial yang lebih seimbang. Nilai-nilai moden seperti rasionaliti, kecekapan, kejayaan, menepati masa dan lain-lain tidak dikesampingkan tetapi ditambah dengan nilai pascamoden seperti imaginasi, sensitiviti, emosi, kemanusiaan dan lain-lain.

c. Paradigma pascamoden menawarkan pandangan yang holistik dan menyeluruh. Ia menyeimbangkan antara pandangan dan cara fikir orang Eropah-Amerika dengan sudut pandang orang Asia melalui usaha meraikan kepelbagaian dan lahirnya pelbagai disiplin ilmu dari kedua-dua belahan dunia yang berbeza dan saling berkombinasi. Ia menyediakan kepada masyarakat global kepada bukan sahaja pandangan yang berdimensikan politik, sosial dan ekonomi seperti yang dibangunkan Barat tetapi juga dimensi dan sudut pandang estetika, etika dan agama yang dikembangkan di Timur.

Oleh itu dari penjelasan di atas, kefahaman Küng mengenai pascamoden bukan merujuk kepada konsep pascamoden menurut kefahaman falsafah seperti yang didefinisikan oleh Lyotard, Welsch dan pemuka 
pascamodenisme yang lain. ${ }^{44}$ Beliau melihat aspek pascamoden sebagai suatu yang berkait dengan sejarah dan perkembangan dunia. ${ }^{45}$ Justeru, paradigma pascamoden merujuk kepada dimensi dan sudut pandang manusia terhadap gugusan persetujuan asas yang bersifat memberi kebaikan untuk manusia, menyanjung kemanusiaan dan meraikan kepelbagaian. Ciri-ciri ini dilihat sebagai suatu keperluan bagi manusia dalam meneruskan survival kehidupan mereka sebagai anggota masyarakat dalam dunia yang plural kini. ${ }^{46}$

Dari huraian mengenai ciri-ciri paradigma ini juga, Küng mengandaikan wujud paradigma sejagat yang diterima oleh setiap agama. Jika sebelum ini agama mempunyai paradigma yang tersendiri namun bagi abad mendatang agama-agama dilihat berpegang kepada paradigma global. Potensi ini wujud berdasarkan pandangan Küng bahawa setiap agama menumpukan kepada persoalan-persoalan asas yang sama walau berbeza paradigma. Ia seperti persoalan berkenaan asal-usul dan kemusnahan dunia, kenapa manusia dilahirkan dan ke mana mereka selepas mati, apa yang menentukan takdir manusia, apa yang menjadi asas untuk moral dan lain-lain. ${ }^{47}$

\section{Analisis Pengaplikasian Teori Paradigma dan Implikasinya terhadap Agama}

Dalam konteks teori paradigma agama, Küng menggambarkan agama sebagai entiti sejarah manusia. Pandangan ini berkait dengan kefahaman beliau yang melihat agama sebagai berevolusi dan berkembang dari ajaran kuno. Beliau berpandangan bahawa agama tidak

44 Untuk maklumat khusus mengenai pascamodenisme lihat JeanFrancois Lyotard, "Answering the Question: What is Postmodernism?," dalam Postmodernism: A Reader, Thomas Docherty, ed. (New York: Harvester Wheatsheaf, 1993), 50.

${ }^{45}$ Hans Küng, Global Responsibility, 3.

${ }^{46}$ Ibid., 22.

${ }^{47}$ Ibid., 128. 
muncul secara bertahap dari bidang yang lain tetapi sedari awal telah muncul sebagai sebuah agama namun secara berstruktur. ${ }^{48}$ Beliau menyanggah pandangan bahawa manusia purba secara sistematik dan bertahap percaya kepada roh atau 'magic' sehinggalah kepada tuhan. Dengan itu beliau tetap melihat berlakunya perkembangan agama, tetapi muncul secara berstruktur dari sifatnya yang primitif dan ringkas, sesuai dengan 'perkembangan intelektual manusia' pada waktu itu kepada agama yang lebih maju dan bersistem. ${ }^{49}$

Berdasarkan kefahaman ini maka agama dilihat perlu difahami melalui sudut pensejarahan. Sekiranya agama kuno dikenalpasti melalui kajian antropologi dan sosiologi maka, bagi mengenalpasti proses perkembangan agama yang wujud kini, teori paradigma dijadikan sebagai metodologi dalam mengenali agama-agama tersebut. Sekurang-kurangnya terdapat dua hujah yang boleh dikemukakan berhubung pandangan ini.

Untuk hujah pertama, pandangan yang melihat agama dengan menggunakan metodologi pensejarahan dengan andaian agama merupakan agama sejarah seharusnya dikhususkan untuk agama tertentu sahaja. Bentuk agama ini tidak mampu dikaji melainkan dengan meneliti sejarah perkembangan agama tersebut yang sentiasa mengalami perubahan menurut suasana dan zaman. Dalam konteks ini teks agama tidak memadai untuk menerangkan pandangan mengenai agama tersebut secara keseluruhan. Ajaran Yahudi (Judaisme) dan Kristian sebagai contoh merupakan ajaran yang lahir dari proses sejarah.

Menurut Richard Niebuhr, kepercayaan, pengamalan, hubungan sosial dan perkembangan sejarah kedua-dua ajaran agama tersebut terbentuk dari himpunan pelbagai idea, nilai dan budaya masyarakat. Dakwaan bahawa

48 Hans Küng, The Beginning of All Things: Science and Religion (Cambridge: William B. Eerdmans Publishing Company, 2007), 167.

${ }^{49}$ Ibid. 
kedua-duanya hanya bersumberkan teks Bible adalah tidak bertepatan dengan gambaran ajaran tersebut pada hari ini. ${ }^{50}$ Beliau menganologikan kelahiran dan perkembangan dua agama ini seperti 'hutan yang muncul dari pelbagai pokok yang tumbuh dari benih yang berasingan' dan bukan seperti 'sebatang pohon yang lahir dari satu benih' ${ }^{51}$ Harvey Cox turut mengakui bahawa Kristian merupakan 'agama Eropah' yang menyerap nilai-nilai kebudayaan orang Barat. ${ }^{52}$

Oleh kerana itu menurut al-Attas, ajaran Kristian difahami oleh para penganutnya hanya melalui jalan pensejarahan (historis). ${ }^{53}$ Tafsiran kepada Bible yang menjadi sumber agama mereka adalah berdasarkan sejarah pertentangan falsafah dan metafizik antara golongan yang

${ }^{50}$ Dengan ini juga tuduhan yang dikemukakan kepada Islam sebagai agama yang ketinggalan zaman kerana masih berpegang kepada hukum-hakam zaman lampau merupakan tuduhan melulu kerana Kristian secara khusus dan Barat secara umum juga masih menyandarkan ajaran dan kebudayaan mereka dengan campuran pandangan falsafah terdahulu. Islam walaubagaimanapun jelas dengan sumbernya dan pengamalan kepada ajaran yang diwahyukan selari bahkan memandu arus kemajuan. Namun bagi Kristian, adunan idea yang saling bercampur dalam ajaran dan pegangan mereka menatijahkan pemikiran yang berkecamuk dan kepercayaan berasaskan andaian yang bersifat tidak pasti. Hasilnya berlaku penolakan terhadap doktrinnya sehingga ia terpaksa pula tunduk kepada keputusan manusia.

51 Dengan hakikat ini Niebuhr menegaskan bahawa pengakuan ajaran Yahudi dan Kristian sebagai suatu sistem ajaran yang tunggal dan berpaksikan monoteisme boleh dipersoalkan. Ini kerana kedua-dua agama yang dimaksudkan hari ini bukan merupakan dua ajaran sebenar seperti sewaktu ia diperkenalkan. H. Richard Niebuhr, Radical Monotheism and Western Culture (Westminster: John Knox Press, 1993), 50.

52 Bagi Cox, dengan adanya sekularisasi, Kristian disebut tidak lagi mewajahkan dirinya untuk orang Barat sahaja tetapi mampu diterima manusia sejagat. Harvey Cox, The Secular City (New Jersey: Princeton University Press, 2013), 108-109.

${ }^{53}$ Al-Attas, Islam and Secularism (Kuala Lumpur: ISTAC, 1993), 12. 
bersandarkan agama dengan golongan rasionalis murni..$^{54}$ Hasilnya sepanjang pertentangan itu, pentafsiran demi pentafsiran dilakukan menyebabkan ajaran Kristian mengalami perubahan sehingga sukar ditentukan aspek keyakinan dalam doktrinnya.

Ia akhirnya dikecilkan menjadi sistem doktrin dan upacara agama yang berkembang dan berevolusi menurut perkembangan dan proses sejarah manusia. Dengan perubahan yang berlaku, aspek agama tidak ditafsirkan menggunakan teologi tetapi berdasarkan ilmu yang mereka kembangkan sendiri seumpama kombinasi sosiologi dan antropologi sehingga kemudiannya menjadi suatu disiplin khusus yang dinamakan falsafah agama.

Jelas di sini, ajaran Yahudi dan Kristian terbentuk dari sumber yang pelbagai di sepanjang perkembangan sejarahnya. Oleh itu, pandangan Yahudi dan Kristian berkenaan kebenaran bukan berasaskan wahyu dan dasar keyakinan agama tetapi berdasarkan tradisi kebudayaan yang dikukuhkan dengan dasar-dasar falsafah yang muncul dari spekulasi serta andaian. Dengan hakikat ini, ia tidak dapat tidak agamawan perlu merelakan ajarannya ditafsir dan disemak agar dilihat sesuai dengan realiti semasa. Metodologi yang bersesuaian untuk menilai perubahan ini ialah dengan analisis paradigma seperti yang dikemukakan. Namun, ciri dan metodologi ini tidak wajar dikaitkan untuk semua agama. Pandangan Küng berkenaan agama sebagai entiti sejarah dilihat terkesan dengan ciri ajaran Kristian yang menjadi anutannya serta kaedah yang digunakan dalam mentafsirkan agama tersebut.

Di samping itu, pandangan agama sebagai entiti sejarah juga boleh dikaitkan dengan pengaruh sekular dalam melakukan penilaian terhadap agama. Menurut al-

54 Menurut Al-Attas, ajaran Kristian sejak awal perkembangannya terpengaruh dengan falsafah dan pandangan alam Aristotle, pengaruh Rom dalam simbol-simbol intelektual dan teologi serta unsur-unsur Barat yang lain. Ibid., 29. 
Attas, kefahaman bahawa agama sebahagian dari perjalanan sejarah merupakan suatu proses sekularisasi yang melihat agama sebagai sistem kepercayaan, amalan, sikap, nilai dan aspirasi yang lahir dari sejarah dan konfrontasi manusia dengan alam. Agama berkembang sebagai suatu hasil dari proses evolusi kesedaran manusia dari 'kesedaran keanak-anakan' menuju 'kedewasaan', serta dari sifat kanak-kanak yang bergantung kepada orang lain kepada kematangan orang dewasa yang melepaskan diri dari bergantung kepada sesuatu termasuk agama. ${ }^{55}$

Dengan ini ia selaras dengan kefahaman perkembangan agama dari suatu yang ringkas sifatnya kemudian menempuh perjalanan sejarah sehingga membentuk agama yang ada kini. Apabila sampai pada suatu masa, manusia tidak lagi memerlukan agama dan ia digambarkan oleh sesetengah pengkaji Barat yang melihat perhatian manusia kini harus ditumpukan kepada sains berbanding agama. Oleh itu melihat agama menurut perspektif sejarah merupakan suatu usaha membebaskan manusia dari bimbingan dan kawalan agama atau campur tangan luar, menerima ciri agama yang sentiasa berubahubah dan anjuran supaya manusia menentukan nasibnya sendiri. Apabila disebut agama sejarah, ruang-waktunya hanya bersekitar kehidupan manusia di dunia, dilihat sementara dan relatif. ${ }^{56}$ Pandangan berkenaan perkembangan agama berdasarkan perubahan sejarah manusia merupakan pandangan sekular yang melihat tiadanya nilai yang mutlak.

Oleh itu untuk hujah kedua, pandangan Küng seperti di atas tidak boleh diaplikasi untuk setiap agama secara umum khususnya Islam. Ini kerana Islam seperti yang telah dihuraikan merupakan ajaran wahyu yang melangkaui proses pensejarahan. Dalam konteks Islam, asas ajaran

\footnotetext{
55 Al-Attas, Islam and Secularism, 26.

${ }^{56}$ Untuk huraian lanjut berkenaan definisi sekular serta unsur-unsur yang membentuknya sila lihat al-Attas, Islam and Secularism, 16-17.
} 
Islam dilihat kepada pandangan alamnya dan bukan kepada paradigma atau perspektif manusia. Pandangan alam menurut Islam ialah pandangan yang melihat kesepaduan rohani dan jasmani serta dunia dan akhirat. Ia adalah pandangan berkenaan dunia, yang merupakan tempat manusia mengumpul amal dan melaksanakan perintah Allah yang dinisbahkan kepada akhirat, yang menjadi tujuan akhir kepada kehidupan. ${ }^{57}$ Setiap tindakan yang dilakukan manusia di dunia adalah berpandukan matlamat yang ingin dicapai di akhirat. Dengan ini tumpuan manusia adalah kepada akhirat tanpa melakukan pengabaian kepada dunia.

Berdasarkan hakikat ini, pandangan alam Islam tidak bersandarkan akal manusia tetapi diasaskan dengan bimbingan wahyu. Alam yang dimaksudkan pula tidak terbatas kepada alam jasmani (dunia) yang menghasilkan pandangan terhadap penglibatan manusia dalam sejarah, masyarakat, politik dan kebudayaan mereka tetapi alam akhirat yang menjadi tempat pengakhiran manusia. ${ }^{58}$ Apa yang digambarkan pada pemikiran juga bukan melibatkan aspek zahir sehingga penumpuan keterlaluan kepada dunia seterusnya dijadikan ia sebagai tujuan hidup, serta bukan pula hanya kepada akhirat sehingga mengabaikan peranan yang perlu dilaksanakan di dunia, tetapi hasil kombinasi kedua-duanya.

Oleh itu pandangan alam Islam suatu yang kekal dan mutlak, melihat hal yang nyata dan juga ghaib, menyeimbangkan aspek rohani dan jasmani serta menyepadukan dunia dan akhirat. Untuk mendapatkan pandangan ini, akal manusia yang terbatas tidak mampu mencapainya. Justeru, pandangan alam Islam berpandukan wahyu Allah SWT. Umat Islam sehingga kini berpegang dengan pandangan alam ini tanpa ada sebarang perubahan.

\footnotetext{
57 Syed Muhammad Naquib al-Attas, Tinjauan Ringkas Peri Ilmu dan Pandangan Alam (Pulau Pinang: Penerbit USM, 2007), 16.

${ }^{58} \mathrm{Ibid}$.
} 
Memasukkan Islam sebagai agama sejarah memberi beberapa implikasi terhadap kedudukan ajaran ini.

Apabila disebut berkenaan sejarah maka ia berkait dengan organisasi sosial manusia serta peradaban yang dibangunkan. ${ }^{59}$ Ia juga berupa kebudayaan masyarakat yang lahir, berkembang menjadi matang, jatuh dan adakalanya lenyap sama sekali. Oleh itu ia sebahagian dari masyarakat dan lahir dari kegiatan yang mereka lakukan. Sekiranya Islam dilihat dari sudut sejarah dan hasil kegiatan masyarakat maka wahyu hanya dilihat sebagai suatu kesan atau peristiwa yang samar dan tidak jelas seperti peristiwaperistiwa yang lain.

Hasilnya ia digambarkan sebagai andaian yang difikirkan oleh pemikiran, perasaan dan imaginasi manusia. Natijahnya agama hanya dilihat sebagai suatu corak pemikiran atau inspirasi dalaman manusia yang diiktiraf suci oleh para penganutnya sahaja. Meletakkan Islam sebagai entiti atau produk sejarah akhirnya hanya merendahkan kedudukan wahyu serta membataskan peranannya.

Sebagai sebahagian dari sejarah, Islam juga akan tertakluk kepada proses perubahan. Dengan itu tidak timbul dakwaan kemutlakan kerana benar-salah tertakluk kepada suasana dan zaman. Sebahagian syariatnya mungkin benar atau munasabah pada sesuatu zaman namun terbuka kepada kesalahan dalam waktu yang lain. Ia juga mungkin sesuai pada waktu ia diperkenalkan berdasarkan realiti dan suasana kemunculannya tetapi mungkin dianggap tidak lagi dapat diamalkan pada masa hadapan sesuai dengan perkembangan dan kemajuan kehidupan.

Di samping itu, Islam yang 'terbentuk' dari tradisi serta adat budaya sesebuah masyarakat akan dilihat sebagai hasil ciptaan dan peninggalan manusia yang diwariskan

59 `Abd al-Raḥmān bin Khaldūn, Muqaddimah al-`Allāmah Ibn Khaldūn (Beirut: Dār al-Fikr, 2008), 50. 
dari satu generasi ke generasi yang lain. ${ }^{60}$ Dengan kedudukan ini Islam tidak lagi dianggap suci kerana bersifat relatif serta tidak mutlak untuk diyakini kerana dilihat sebagai suatu pilihan. Kesemua ciri-ciri yang disebutkan ini terdapat pada ajaran agama yang lain namun ia tidak menepati hakikat ajaran Islam yang berasaskan keyakinan yang kukuh dan pengamalan berdasarkan syariat yang telah ditetapkan.

Namun, apakah Islam mampu ditafsirkan melalui analisis kepada 'paradigma-paradigmanya'? Penjelasan Küng berkenaan paradigma adalah kabur. Walaupun disebut bahawa terdapat ciri bersifat tetap dan yang boleh berubah dalam setiap paradigma namun beliau tidak memberi batasan yang jelas berkenaan perbezaan keduaduanya. Paradigma yang didefinisikan oleh beliau juga hanyalah tertumpu kepada aspek zahir sahaja. Natijahnya, pandangan berkenaan agama terbatas kepada himpunan pelbagai perkara, nilai dan penjelmaan kebudayaan yang terjelma dalam kehidupan yang dilalui komuniti agama. ${ }^{61}$ Paradigma seperti ini tidak boleh dinisbahkan kepada Islam kerana ia tidak menggambarkan agama secara keseluruhan. Gambaran mengenai agama yang bercampur dengan sumber yang lain hasil gambaran pengamalan masyarakat hanya mencerminkan pengamalan beragama dan bukan agama itu sendiri.

Oleh itu, paradigma yang diutarakan Küng merupakan perspektif manusia hasil dari peristiwa atau fakta yang berubah menurut perkembangan zaman. Ia merupakan pandangan yang bersifat sementara dan terbuka demi membolehkan perubahan mendatang untuk digantikan dengan paradigma yang lain. Apabila timbul sesuatu masalah maka paradigma yang lain diperlukan bagi

\footnotetext{
${ }^{60}$ Muhammad Sa ìd Ramaḍān al-Būtị, Fiqh al-Sirah al-Nabawiyyah: Ma`a Mawjiz li Tārīkh al-Khilāfah al-Rāshidah (Damsyik: Dār alFikr, 2007), 115-116.

${ }^{61} \mathrm{Ibid}$.
} 
mengatasinya. Akhirnya aspek hakikat dilihat perlu sentiasa menempuh perubahan asasi bagi meneruskan kelangsungan kewujudannya. ${ }^{62}$ Ini terjadi apabila beliau mengambil pendekatan sains tabii dalam melakukan penelitian terhadap agama. Ia membuka ruang kepada ciriciri yang ada pada paradigma sains untuk digunakan kepada agama. Contohnya ciri perubahan pada sains tabii yang boleh diujikaji dan dieksperimenkan disamakan dengan agama yang merupakan suatu keyakinan yang seharusnya bersifat mutlak dan kekal.

Küng mengatakan paradigma bukan agama tetapi agama sebahagian darinya. Pandangan ini menunjukkan kelemahan agama yang seharusnya berperanan mencorakkan pemikiran manusia tetapi sebaliknya perlu tunduk kepada perspektif manusia. Dengan ini, agama tidak membentuk pandangan alam, tetapi pandangan alam yang terhasil dari kombinasi idea dan kebudayaan manusia yang membentuk agama. Dakwaan bahawa agama hidup dan berkembang pada setiap zaman dengan paradigmaparadigma yang berbeza memperlihatkan pengaruh pemikiran manusia terhadap agama dan bukan sebaliknya. Selain itu, konsep paradigma yang didakwa sinonim dengan pemikiran manusia yang sentiasa berkembang telah dijadikan justifikasi untuk setiap agama berubah. Metodologi ini digunakan oleh Küng dalam mewajarkan setiap agama untuk berpegang kepada ramalan paradigma pascamoden beliau.

Namun, bukan beliau sahaja yang mengaplikasikan teori paradigma ini ke dalam bidang agama tetapi telah wujud sebahagian pihak yang menjadikannya satu-satunya metodologi untuk mencipta revolusi 'ilmiah' dalam bidang teologi dan falsafah agama. Wilfred C. Smith, pelopor idea teologi global iaitu satu faham pengistilahan baru agama yang dilihat kepada tradisi manusia turut menggunakan paradigma sebagai menjustifikasikan pentafsiran semula

62 Ibid., 17. 
agama. Begitu juga dengan John Hick yang menggagaskan idea evolusi agama dari pemusatan kepada satu agama sahaja kepada pemusatan Tuhan yang mengemukakan kepentingan perubahan agama berpandukan paradigma ini. ${ }^{63}$

Oleh itu, metode yang digunakan ini diaplikasi untuk setiap bidang termasuk agama. Oleh kerana agama dikaitkan dengan pemikiran manusia maka metode ini dilihat seolah paling wajar dalam menggambarkan sesuatu perubahan.

\section{Rumusan}

Sebagai rumusannya, analisis paradigma agama dan perubahannya merupakan metodologi Küng dalam memahami agama. Ia merupakan satu usaha duplikasi teori dan metodologi yang diperkenalkan oleh Thomas Kuhn namun berbeza dari sudut sasaran dan bentuk perubahannya. Dari huraian yang dijelaskan di atas, Küng dilihat berjaya membentuk teori paradigmanya yang tersendiri dan tidak bergantung sepenuhnya dengan teori Kuhn.

Melalui teori paradigma ini beliau meneliti beberapa aspek agama seperti pensejarahan, perkembangan agama yang telah berlaku, situasi semasa yang sedang berlaku dan ramalan atau andaian masa depan agama tersebut berdasarkan sejarah dan situasi semasanya. Berdasarkan kaedah ini, boleh dikatakan bahawa penilaian dan pentafsiran terhadap agama menurut perspektif beliau perlu dilihat kepada aspek sejarah dan bukannya sekadar berpandukan ajaran semata-mata. Pengkajian agama berdasarkan konteks paradigma ini dikatakan lebih komprehensif dan lengkap.

${ }^{63}$ David J. Bosch, Transforming Mission: Paradigm Shifts in Theology Mission (New York: Orbis Books, 2011), 495 dan Anis Malik Thoha, Tren Pluralisme Agama: Tinjauan Kritis (Jakarta: Perspektif, 2006), 76-77. 
Walau bagaimanapun teori paradigma yang digunakan oleh Küng ini menimbulkan beberapa persoalan khususnya dari sudut metodologi yang digunakannya. Beliau berjaya menzahirkan perbezaan jelas konsep anjakan paradigmanya dengan paradigma Kuhn namun tidak menghuraikan secara terperinci berkenaan metodologi yang digunakan dalam mengenalpasti tahap-tahap paradigma dan anjakan yang berlaku. Selain itu, beliau tidak menjelaskan bagaimanakah sesebuah paradigma yang disusun oleh seseorang pengkaji itu sahih dan tepat, apakah sumbernya dan bagaimanakah penelitian dibuat dalam mengukur perspektif penganut ketika berpegang kepada satu-satu paradigma yang berbeza.

\section{Rujukan}

Al-Attas, Syed Muhammad Naquib. Islam and Secularism. Kuala Lumpur: ISTAC, 1993.

Al-Attas, Syed Muhammad Naquib. Tinjauan Ringkas Peri Ilmu dan Pandangan Alam. Pulau Pinang: Penerbit USM, 2007.

Anis Malik Thoha. Tren Pluralisme Agama: Tinjauan Kritis. Jakarta: Perspektif, 2006.

Bosch, David J. Transforming Mission: Paradigm Shifts in Theology Mission. New York: Orbis Books, 2011

Brugger, Bill dan Hannan, Kate. Modernisation and Revolution. Kent: Croom Helm Ltd, 1983.

Al-Būṭi, Muḥammad Sa ìd Ramaḍān. Fiqh al-Sīrah alNabawiyyah: Ma`a Mawjiz li Tārīkh al-Khilāfah alRāshidah. Damsyik: Dār al-Fikr, 2007.

Copleston, Frederick. A History of Philosophy: Logical Positivism and Existentialism. New York: Continuum, 2003.

Cox, Harvey. The Secular City. New Jersey: Princeton University Press, 2013.

Cross, F.L. dan Livingtone, E.A. The Oxford Dictionary of the Christian Church. Oxford: Oxford University Press, 2005. 
Deane, Jennifer Kolpacoff. A History of Medieval Heresy and Inquisition. Plymouth: Rowman \& Littlefield Publishers 2011.

Gattei, Stefano. Thomas Kuhn's "Lingusitic Turn" and the Legacy of Logical Empiricism: Incommensurability, Rationality and the Search for Truth. Hampshire: Ashgate Publishing Limited, 2008.

Ibn Khaldūn, Muqaddimah al-`Allāmah Ibn Khaldūn. Beirut: Dār al-Fikr, 2008.

Kuhn, Thomas S. The Structure of Scientific Revolutions. Chicago: The University of Chicago Press, 1970.

Küng, Hans. Global Responsibility: In Search of a New World Ethic terj. John Bowden. Oregon: Wipf and Stock, 1991.

Küng, Hans. Islam: Past, Present and Future. Oxford: Oneworld Publications 2007.

Küng, Hans. The Beginning of All Things: Science and Religion. Cambridge: William B. Eerdmans Publishing Company, 2007.

Küng, Hans. Theology for the Third Millennium: An Ecumenical View. New York: Doubleday, 1988.

Lyotard, Jean-Francois "Answering the Question: What is Postmodernism?" Dalam Postmodernism: A Reader, ed. Thomas Docherty. New York: Harvester Wheatsheaf, 1993.

Megill, Allan. Historical Knowledge, Historical Error: A Contemporary Guide to Practice. London: The University of Chicago Press, 2007.

Najiah Martiyam ed. Jalan Dialog Hans Kung dan Perspektif Muslim, terj. Mega Hidayati et.al. Yogyakarta: Program Studi Agama dan Lintas Budaya, t.t.

Nickles, Thomas. Thomas Kuhn. Cambridge: Cambridge University Press, 2003.

Niebuhr, H. Richard. Radical Monotheism and Western Culture. Westminster: John Knox Press, 1993. 
Mohd Khairul Naim, "Analisis Teori Paradigma Hans Küng dalam Kajian Agama," Afkār Vol. 20 Issue 1 (2018): 143-178

Roudometof, Victor et. al. Eastern Orthodoxy in a Global Age: Tradition Faces the Twenty-First Century. California: AltaMira Press, 2005.

Sheppard, James A. Christendom at the Crossroads: The Mediaeval Era. Kentucky: Westminster John Knox Press, 2005.

Tartakoff, Paola. Between Christian and Jew: Conversion and Inquisition in the Crown of Aragon, 1250-1391. Pensylvania: University of Pensylvania Press, 2012

Willert, Trine Stauning dan Liederman, Lina Molokotos. Innovation in the Orthodox Christian Tradition?: The Question of Change in Greek Orthodox Thought and Practice. Surrey: Ashgate Publishing Limited, 2012. 